\title{
PENINGKATAN KEMAMPUAN MEMBUAT KUIS ONLINE GURU MADRASAH IBTIDAIYAH (MI) NURUL ISLAM WONOKALANG WONOAYU SIDOARJO MELALUI PELATIHAN APLIKASI KUIS INTERAKTIF BERBASIS QUIZIZZ
}

\author{
Arie Widya Murni ${ }^{1}$, Masyitah Noviyanti ${ }^{2}$, Athika Dwi Wiji Utami ${ }^{3}$ \\ ${ }^{1}$ Pendidikan Guru Sekolah Dasar, FKIP, Universitas Nahdlatul Ulama Sidoarjo \\ ${ }^{2}$ Pendidikan Bahasa Inggris, FKIP, Universitas Nahdlatul Ulama Sidoarjo \\ ${ }^{3}$ Desain Komunikasi Visual, Fak. Ilmu Komputer, Universitas Nahdlatul Ulama Sidoarjo \\ Jl. Monginsidi Dalam Kav. DPR Sidoklumpuk Sidoarjo \\ ariewidya.pgsd@unusida.ac.id ${ }^{1}$, noviyuska@gmail.com ${ }^{2}, \underline{\text { athikautami@gmail.com }}^{3}$
}

\begin{abstract}
ABSTRAK
Telah dilakukan kegiatan pengabdian kepada masyarakat dengan judul pelatihan penggunaan aplikasi quizizz bagi guru MI Nurul Islam Wonokalang Wonoayu Sidoarjo. Kegiatan ini berlangsung selama dua hari bertempat di ruang aula MI MI Nurul Islam Wonokalang Wonoayu. Tujuan dari kegiatan ini adalah memberikan wawasan pengetahuan dan keterampilan terkait dengan pembuatan kuis menggunakan aplikasi quizizz. Sasaran kegiatan ini adalah semua guru kelas I s.d VI MI Nurul Islam Wonokalang Wonoayu Sidoarjo sejumlah 12 orang peserta. Metode yang digunakan dalam kegiatan pengabdian ini adalah metode pengarahan, diskusi, tanya jawab, praktik secara langsung di lapangan, dan pendampingan. Para peserta sangat antusias mengikuti kegiatan ini karena sebagian besar guru belum pernah membuat kuis menggunakan aplikasi quizizz. Setelah mengikuti kegiatan ini para peserta diharapkan dapat membuat kuis sesuai dengan materi yang diajarkan pada peserta didik.
\end{abstract}

Kata Kunci: pelatihan, aplikasi quizizz, kuis interaktif online

\section{ABSTRACT}

The community services under the theme Quizizz Application Implementation Workshop for MI Nurul Islam Wonokalang, Wonoayu was done in two days, started at 12 and 13 August 2020 located at MI Nurul Islam Wonokalang Wonoayu. This workshop aimed to give any broader knowledge and skills related to the implementation of quizizz application. The objects were teachers of MI Nurul Islam consist of 12 persons. The methods used was direction, discussion, question and answer, and practice methods. The attendants were enthusiastic because using the application was the new thing in their teaching learning activity. After attending the workshop, it was expected for the teachers to apply the application based on the material prepared for the students.

Keywords: workshop, quizizz application, online interactive quiz

\section{PENDAHULUAN}

Akhir tahun 2019 berbagai negara telah dikejutkan dengan adanya pandemi covid-19 yang menyebabkan angka kematian begitu tinggi. Dengan adanya covid-19 menjadi permasalahan baru yang harus dihadapi oleh semua orang termasuk para pendidik pada masa kini. Sebagai upaya untuk menanggulangi pandemi covid-19 telah terbentuk kebijakan baru, 
diantaranya social distancing, work from home, learn from home, hingga lockdown bagi negara yang terdampak, termasuk negara Indonesia.

Indonesia menjadi salah satu negara yang terdampak pandemi covid-19 dengan tingkat perkembangan semakin hari semakin cepat menyebar ke sejumlah wilayah yang ada di Indonesia. Semenjak pandemi covid-19 yang menimpa Indonesia beberapa bulan ini telah menyebabkan perubahan yang besar dalam berbagai aspek kehidupan, mulai dari aspek ekonomi, sosial, budaya, agama, dan juga pendidikan.

Kepatuhan akan peraturan pemerintah terkait dengan melaksanakan kebijakan social distancing, work from home, dan learn from home untuk menghentikan laju penyebaran covid-19 telah menyebabkan pergeseran paradigma pendidikan di Indonesia pada masa saat ini. Dampak yang sangat jelas dan nyata dalam dunia pendidikan yaitu telah terjadinya penggunaan teknologi sebagai pergeseran arah pembelajaran, dari yang biasanya melakukan pembelajaran dengan cara tatap muka, sekarang berubah menjadi pembelajaran yang sifatnya daring atau jarak jauh tanpa melakukan tatap muka.

Para pendidik berupaya untuk mencari alternatif dalam menanggulangi pandemi ini, diantaranya yaitu dengan memanfaatkan teknologi games-based learning guna memberikan pengalaman pembelajaran yang nantinya mampu meningkatkan keikutsertaan peserta didik dalam pembelajaran. Aplikasi quizizz sebagai platform teknologi pembelajaran yang mengombinasikan pengalaman evaluasi pembelajaran melalui permainan interaktif yang dilengkapi dengan sistem pengawasan bagi aktivitas peserta didik. Inovasi penggunaan aplikasi quizizz ini mampu membantu para guru dalam aktivitas evaluasi pembelajaran sehingga menjadi menarik, interaktif, dan dapat dikaitkan dengan aplikasi google classroom sehingga memudahkan untuk memantau hasil belajar peserta didik.

Pada wilayah kabupaten Sidoarjo yang termasuk dalam kategori zona merah, terdapat banyak sekolah dasar baik negeri maupun swasta yang mengalami kesulitan dalam melaksanakan pembelajaran daring dari rumah. Sebagian besar guru-guru hanya mengandalkan kemampuannya dalam memberikan tugas dan memantau dengan aplikasi whats app group (WAG). Sedangkan pada kenyataannya dengan sebatas WAG semakin membuat kejenuahn pada peserta didik, karena tidak adanya interaksi yang bagus dan cenderung monoton dengan meminta mnegerjakan tugas, tugas, dan tugas.

Berdasarkan hasil observasi di lapangan diperoleh data bahwa MI Nurul Islam Wonokalang perlu dimaksimalkan potensinya melalui pelatihan dalam hal penggunaan 
aplikasi quizizz. MI Nurul Islam Wonokalang merupakan sekolah yang terletak di Kecamatan Wonoayu Kabupaten Sidoarjo dengan akreditasi sangat baik. Setelah dilakukan observasi dan wawancara terhadap para guru, ternyata masih banyak guru-guru yang belum menguasai aplikasi pembelajaran yang dapat digunakan secara daring dengan tujuan membuat peserta didik semangat untuk belajar meski dari rumah. Salah satu penelitian yang dapat dijadikan contoh adalah penelitian Wahyuni (2019:182) yang mendapatkan data bahwa peserta didik dapat lebih semangat jika belajar dengan melibatkan teknologi. Sehingga menjadi alasan utama dilakukan pengabdian di MI Nurul Islam Wonokalang.

Aplikasi pembelajaran yang sangat bermanfaat bagi guru adalah salah satunya quizizz. Menurut Nugroho (2019) Quizizz merupakan sebuah web tool untuk membuat permainan kuis interaktif untuk digunakan dalam pembelajaran di kelas. Selain itu, aplikasi quizizz ini menjadikan sebuah pembelajaran sangat digemari, karena sangat mudah dalam pembuatan konten, membuat soal, pekerjaan rumah, tes dan kuis serta tampilan yang menarik bagi peserta didik.

Aplikasi quizizz ini memiliki keungulan diantaranya (1) setiap peserta didik menjawab pertanyaan dengan benar maka akan muncul beberapa poin yang didapat dalam satu soal dan juga mendapat peringkat dalam menjawab soal tersebut; (2) apabila peserta didik menjawab salah dalam pertanyaan tersebut, maka akan muncul jawaban yang benar; (3) jika selesai mengerjakan kuis, pada akhir kuis akan ada tampilan review question untuk melihat kembali jawaban yang telah dipilih; (4) dalam pengerjaan kuis, setiap peserta didik mendapat daftar pertanyaan yang berbeda dengan peserta didik lain karena kuis dibuat dalam bentuk pekerjaan rumah dan daftar soal diacak, sehingga setiap soal yang muncul berbeda-beda; (5) aplikasi quizizz dapat disambungkan dengan aplikasi google classroom. Selain keunggulan, aplikasi ini memiliki kelemahan, yaitu peserta didik dapat membuka tab baru dan cukup susah mengontrol peserta didik ketika membuka tab baru.

\section{METODE}

Kegiatan pelatihan ini dilakukan pada tanggal 13 Agustus 2020 di MI Nurul Islam Wonokalang Wonoayu Sidoarjo. Metode penelitian ini dengan pengarahan, diskusi, tanya jawab, praktik secara langsung di lapangan, dan pendampingan. Sasaran peserta pelatihan terdiri atas semua guru kelas I-VI sejumlah 12 orang peserta. Pemateri dalam pelatihan aplikasi quizizz yaitu Arie Widya Murni, S.Pd., M.Pd., Masyitah Noviyanti, M.Hum., dan 
Athika Dwi Wiji Utami, M.Pd. yang memiliki kepakaran dalam bidang media dan teknologi pembelajaran.

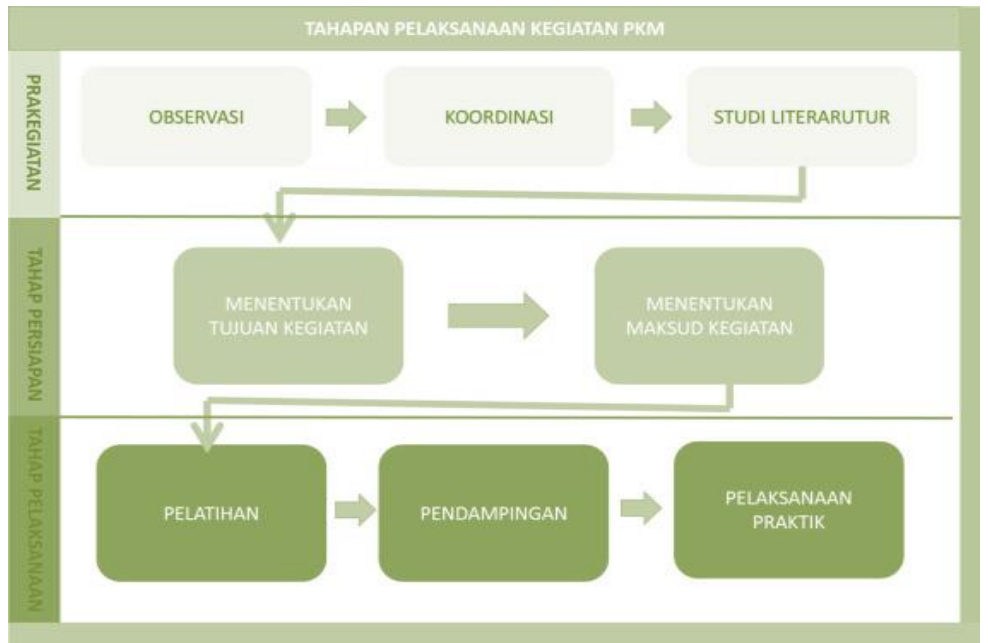

Gambar 1. Metode Pelaksanaan Pengabdian

Tahapan pelatihan ini dibagi menjadi tiga yaitu pra kegiatan, persiapan dan pelaksanaan. Tahap pra kegiatan dilakukan dengan observasi, koordinasi dengan pihak sekolah, dan pendalaman terkait dengan studi literature. Selanjutnya tahap persiapan terdiri atas menentukan tujuan kegiatan dan menentukan maksud kegiatan yakni dengan mempersiapkan narasumber, persiapan panitia pelatihan berupa surat, administrasi, serta fasilitas. Tahap pelaksanaan terdiri atas tahap pelatihan yakni pemberian materi, diskusi terbatas, pendampingan, dan pelaksanaan praktik penggunaan aplikasi serta evaluasi.

Kegiatan ini meliputi pelatihan menggunakan aplikasi pembelajaran yang dapat dimanfaatkan guru di kelas. Aplikasi gratis atau tidak berbayar ini dapat dimanfaatkan oleh guru-guru guna menstimulus peserta didik sehingga pembelajaran dapat berlangsung dengan sangat baik dan interaktif meski dilaksanakan dari rumah. Setelah pemaparan materi selesai, dilakukan praktik menggunakan aplikasi quizizz yang dibimbing oleh tim pengabdian.

Pada kegiatan pelatihan ini guru-guru sangat antusias untuk mencoba permainan pembelajaran didalam kegiatan praktiknya. Selain itu, karena waktu yang sangat terbatas, peserta pelatihan diberikan tugas mandiri untuk dikerjakan di rumah membuat kuis sesuai dengan kelas dan materi yang akan diberikan kepada peserta didik. Pendampingan dilakukan bersambung terhitung selama 32 jam sehingga guru terampil dalam menggunakan aplikasi quizizz saat pembelajaran bersama peserta didik. 


\section{HASIL DAN PEMBAHASAN}

Pelatihan menggunakan aplikasi pembelajaran quizizz dapat dimanfaatkan guru secara daring bersama dengan peserta didiknya. Aplikasi gratis tak berbayar ini sebenarnya dapat digunakan guru untuk menstimulus peserta didik sehingga pembelajaran berlangsung interaktif dan tidak monoton meski dikerjakan dari rumah peserta didik masing-masing.

Sebelum peserta mulai dilatih menggunakan games-based learning atau pembelajaran berbasis permainan, para peserta yakni guru-guru melakukan pretest terlebih dahulu guna mengetahui sejauh mana pemahaman terkait dengan aplikasi yang hendak dilakukan. Dari hasil rata-rata prestest yang dilakukan didapat hasil 48,75 dengan kategori kurang. Melihat hasil tersebut, pemateri secara perlahan memberikan pemaparan materi kepada para peserta.

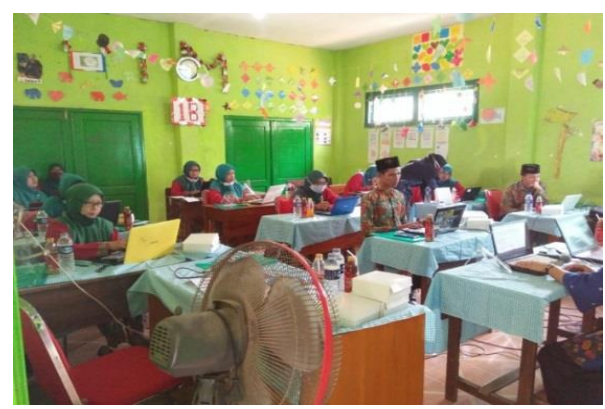

Gambar 2. Kegiatan melakukan pretest

Setelah pemaparan materi selesai dilakukan, langkah selajutnya yaitu dengan praktik menggunakan aplikasi quizizz yang dibimbing oleh tim pengabdian. Peserta kegiatan dilatih dalam membuat kuis online. Kemudian setelah selesai membuat kuis tersebut, peserta mencoba untuk mensimulasikan hasil pembuatan kuis tersebut sebelum diberikan kepada peserta didik.
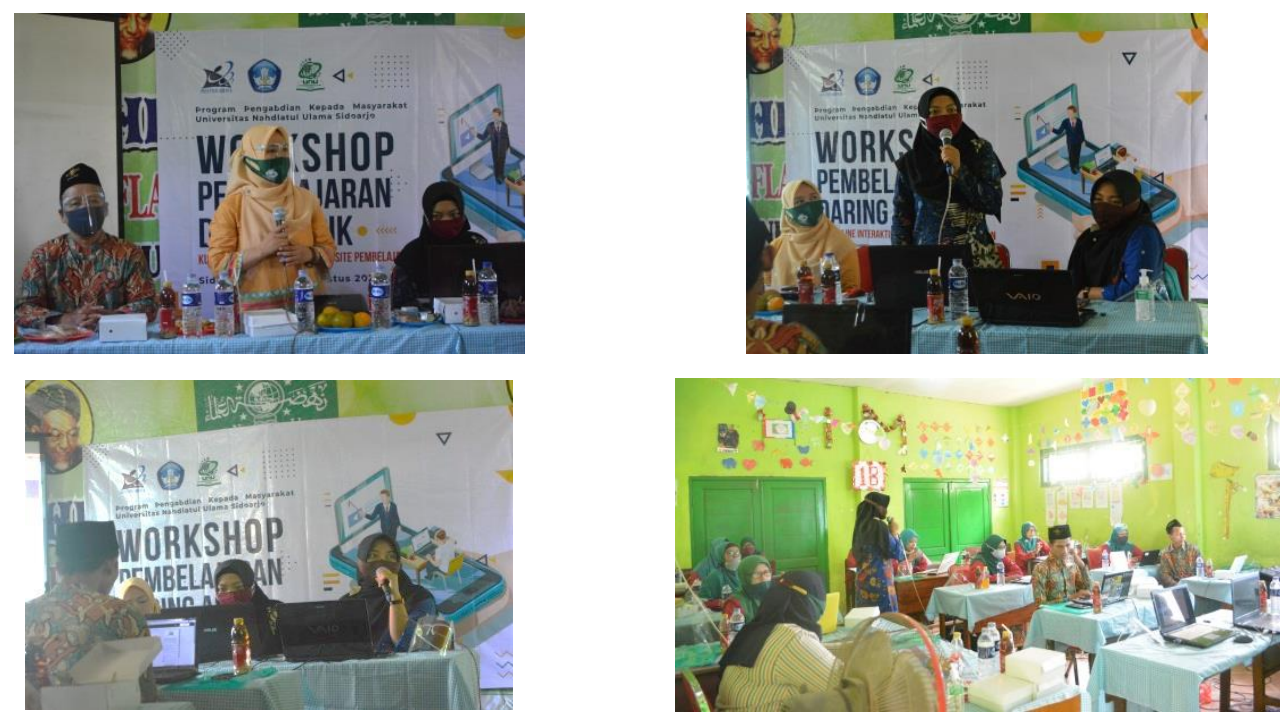

Gambar 3. Kegiatan melakukan pemaparan pelatihan aplikasi quizizz. 
Sebelum peserta membuat akun dan kuis sendiri berdasarkan kebutuhan dalam pembelajaran bersama peserta didik. Indikator keberhasilan untuk masing-masing peserta adalah jika mampu membuat akun dan kuis di aplikasi quizizz, serta berhasil memposting kuis ke dalam google classroom yang telah tim pengabdian sediakan. Kegiatan pendampingan berlangsung secara serius dan antusias, sembari sesekali bertanya kepada tim jika mengalami kendala saat mempelajari dan mempraktikkan aplikasi quizizz. Setelah pendampingan pelatihan berakhir, didapat 12 peserta mampu membuat akun dan kuis di aplikasi quizizz serta berhasil memposting ke dalam google classroom. Maka dapat dikatakan $100 \%$ peserta mengalami peningkatan keterampilan dalam penggunaan aplikasi quizizz yang dikemas dalam pembelajaran berbasis permainan.
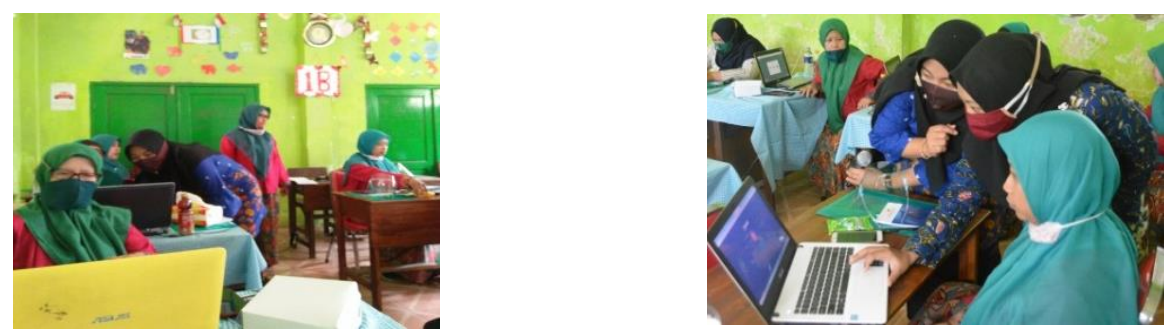

Gambar 4. Kegiatan melakukan pendampingan pelatihan aplikasi quizizz.

\section{SIMPULAN}

Pelatihan aplikasi kuis interaktif berbasis quizizz bagi guru MI Nurul Islam Wonokalang Kecamatan Wonoayu Kabupaten Sidoarjo berdampak pada peningkatan kemampuan guru-guru dalam membuat kuis online dalam pembelajaran. Selain itu, terdapat motivasi yang tinggi dari para peserta yakni guru-guru dalam mengaplikasikan kuis interaktif berbasis quizizz pada pembelajaran daring. Praktik pembelajaran menggunakan aplikasi kuis interaktif berbasis quizizz yang dilakukan pada kelas rendah sampai dengan kelas tinggi sekolah dasar ini dapat membuat peserta didik bersemangat dalam belajar dari rumah serta guru dapat memanfaatkannya dalam mengevaluasi peserta didik dan menambah sumber belajar bagi peserta didik.

\section{DAFTAR PUSTAKA}

Fazriah, Nurul. 2020. Pelatihan Aplikasi Pembelajaran Quizizz di Sekolah dasar Kota Bandung. ETHOS (Jurnal Penelitian dan Pengabdian Masyarakat),8(2),199-204. https://doi.org/10.52553/ethos.v8i2.4455

Nugroho, Irfan Adi. 2019. Pembuatan Soal Menggunakan Aplikasi Quizizz. Jogjakarta: LP3M Sarjana Wiyata Taman Siswa 
Abdimas Berdaya: Jurnal Pengabdian Masyarakat

Vol. 3 No. $02(2020)$

P-ISSN: 2685-1563, E-ISSN: 2720-9768

Wahyuni, S. E., Widiyatun, F., Widyasari, H., \& Suharmanto, P. 2019. Peningkatan Semangat Belajar dengan Peta Konsep dan Media Pembelajaran menggunakan Program Mindmapple. ETHOS (Jurnal Penelitian Dan Pengabdian), 7(2), 178181.https://doi.org/10.29313/ethos.v7i2.4415 